\title{
TREATMENT OF HAEMOPHILUS INFLUENZAE MENINGITIS
}

\author{
F. J. Schulte and M. Vollrath
}

Department of Pediatrics University of Göttingen

Once every few years new interest in the treatment of the meningitides is revived either since new information about the first choice antibiotics become available, or since follow-up studies reveal that the results are not as good as it is commonly believed. Both is particularly true for $\mathrm{H}$. influenzae meningitis.

From several recent publications we know that the mortality can be as high as $17 \%$ and ranges probably around $10 \%$, that about $35 \%$ may suffer from significant intellectual and/or neurological handicaps, that hearing defects occur in $2-3 \%$ of the cases and that the so-called normal survivors are significantly different from matched controls as to their intellectual performance (Siproles et al. 1969; Sell et al. 1972; GAMSTORP and KLOCKHOFF 1974).

Furthermore, with rigid therapeutic regimes some side effects became apparent which, although rare or even remote, require some second thoughts about risks versus residuals (SCHRÖTER 1974, Gamstorp and KlockHorf 1974).

The controversy about adequate treatment of $\mathrm{H}$. influenzae meningitis again concentrates around the ques- tion "chloramphenicol versus ampicillin". Neither in vitro (KHAN et al. 1966) nor clinical studies (Mathies et al. 1965, Fleming et al. 1965) could find one drug principally superior to the other. This finding is particularly important since sometimes the bacteriocidic effect of ampicillin was discussed against the bacteriostatic effect of chloramphenicol. Theoretically, chloramphenicol has some advantage because of a consistent serum/CSF ratio of about $40 \%$ during the whole course of the treatment rather independent from CSF cell count or protein (MCCRUMB et al. 1951). CSF ampicillin levels, on the other hand, were found to be more inconsistent and the factors which influence the serum/CSF ratio of this drug are still only partly known: dose, route and interval of administration, CSF protein and meningeal inflammatory reaction, renal function even without clinical signs of failure or diuresis, shock etc. Even if patients with overt renal failure were excluded the CSF values were unpredictable, although with 150$200 \mathrm{mg} / \mathrm{kg} /$ day during the first three days of treatment - when cell count and protein were high - "most of the time" sufficient levels were reached 
(Thrupp et al. 1965). It is noteworthy, however, that in 12 out of $128 \mathrm{CSF}$ specimens these authors could not detect ampicillin (less than $0,03 \mathrm{mg}$ ! $\mathrm{ml})$ : two of these patients were treated with ampicillin for meningococcal, four for pneumococcal and six for $H$. influenzae meningitis. In all cases lack of ampicillin in the CSF was also noted during the first three days of treatment, when it is particularly dangerous. Thus, with ampicillin rather high doses of $200-400 \mathrm{mg} / \mathrm{kg} / \mathrm{day}$ in 4 hours intervals via the i. v. or i. m. route are suggested in order to avoid. therapeutic failure (CHERrY and SHEeNAN 1968, Young et al. 1968, Levine et al. 1970, Greene 1968, Smith 1974). However, no significant correlation could be found between CSF drug levels and follow-up studies.

More recently, ampicillin resistent $H$. influenzae have been reported from the US, the United Kingdom and possibly from Germany (CLYMO and HARPER 1974, Khan et al. 1974, NeLson 1974, SChiffer et al. 1974, Thomas et al. 1974, Томен et al. 1974, Turk 1974). "The Committee on Infections of the American Academy of Pediatrics has recently recommended that all systemic infections believed to be caused by $\mathrm{H}$. influenzae be treated with chloramphenicol until the organism is shown to be sensitive to ampicillin" (Gardner 1974). However, sensitivity tests for $\mathrm{H}$. influenzac are particularly difficult and not readily available in smaller hospitals (McLinN et al. 1970).
Because of the reported variance in CSF ampicillin levels we ourselves did never change to ampicillin in the treatment of the meningitides and continued to use double therapy (penicillin and chloramphenicol) in purulent meningitis of unknown origin and chloramphenicol alone in a dose of $100 \mathrm{mg} / \mathrm{kg} /$ day, once $\mathrm{H}$. influenzac was clearly diagnosed in the cultures. From 1963-1973 twenty-three consecutive cases were thus treated. In the earlier years treatment was continued sometimes as long as $20-25$ days. Later, according to international agreement, the drug was discontinued 4 days after the child became afebrile, provided that the CSF cell-count was mononuclear and below 30 per cubic millimeter, that the protein concentration was less than $50 \mathrm{mg} / 100 \mathrm{ml}$ and that all other signs of an acute inflammatory reaction were disappearing. Thus, the duration of treatment was reduced to less than 15 days. However, we still always exceed the socalled maximum dose of $700 \mathrm{mg} / \mathrm{kg}$ chloramphenicol in children with $\mathrm{H}$. influenzae meningitis. All our patients were followed both by a pediatric neurologist and a psychologist. From the 23 children only one died ( 30 minutes after admission), one child, who was admitted 7 days after the onset of the illness has neuro-psychiatric sequelae and only one other has a hearing defect. Thus, $84 \%$ of our patients recovered completely. Severe hematologic or other side effects of chloramphenicol were not seen in this hospital. 
However, at the moment for some authors it may still not seem justified to treat every purulent meningitis of unknown origin or every $\mathrm{H}$. influenzae meningitis with chloramphenicol. The situation becomes again debatable, if Dr. GaMSTORP's (1974) experience with a high percentage of hearing defects after ampicillin therapy of $\mathrm{H}$. influenzae meningitis can be demonstrated in a larger series of cases and if ampicillin resistent $H$. influenzae will be found in one's own area. Once can at least make a strong case for chloramphenicol in all those patients with proven or suspected $H$. influenzae meningitis, in which neuropsychiatric symptoms such as apathy or even unconsciousness, convulsions and shock as well as poor meningeal inflammatory reaction do not allow to run any risk of therapeutic delay due to inconsistent CSF drug levels or due to questionable sensitivity of the organism. From the data reported so far no support can be derived for using ampicillin during the first days of treatment and then changing to chloramphenicol, when CSF cell count and protein are such, that the ampicillin concentration in the CSF is likely to be very low. There ist strong evidence from the literature, that the efficiency of the treatment during the first days determines the ultimate outcome. Practically all deaths and the major complications occur during the first 3 days. A combination of ampicillin and chloramphenicol is probably dangerous since the two drugs are likely to be antagonistic (Haltalin and SMIth 1971).

In this issue of our Journal we asked Dr. LORBER to present his view on the treatment of $\mathrm{H}$. influenzae meningitis, which differs somewhat from current practice but, nevertheless, seems to be equally succesful.

\section{References}

1. Cherry, J. D. and Sheeman, C. P.: Bacteriologic relapse on hemophilus influenzae meningitis. New England J. of med. 278, 1001 (1968) - 2. Clymo, A. Bi and Harper, I. A.: Ampicillin-resistant Haemophilus influenzae meningitis. Lancet 1, 453 (1974) - 3. FlemMING, P. C., Murray, J. D. M., Fujiwara, M. W., Prichard, J. S. and McNeughton, G. A.: Ampicillin in the treatment of bacterial meningitis. Antimicrobial Agents and Chemotherapy 2, 47 (1966) - 4. GAMSTORP, I. and KlockHOFF, I.: Bilateral, severe, sensorineural hearing loss after haemophilus influenzae meningitis in dildhood. Neuropädiatrie 5, 121 (1974) - 5. Gardner, P.: Antimicrobial Drug Therapy in Pediatric Practice. Pediatric Clinics of North America 21, 617 (1974) - 6. Greene, H. L.: Failure of ampicillin in meningitis. Lancet 1, 861 (1968) - 7. Haltalin, K. C. and Smirh, J. B.: Reevaluation of ampicillin therapy for Hemophilus influenzae meningitis: An appraisal based on a review of cases of fersistent or recurrent infection. Am. J. Dis. Child 122, 328 (1971) - 8. Khan, W., Ross, S. and Zaremba, E. A.: Comparative inhibition of $H$.influenzae by eight antibiotics. Antimicrobial Agents and Chemotherapy 6, 393 (1966) 9. Khan, W., Ross, S., Rodriguez, W., ConTRONI, G. and $S_{A Z}, A$. K.: Haemophidus influenzac Type B Resistant to Ampicillin. J. A. M. A. 229, 298 (1974) - 10. Levine, M. S., Boxerbaum, B. and Heggie, A. D.: Redrudescence of $H$. influenzae meningitis after therapy with ampicillin. Clinical Pediatrics 9, 54 (1970) - 11. Mathies, A. W., Leedom, J. M., Thrupp, L. D., Ivler, D., Portnoy, B. and WeHrle, P. E.: Experience with ampicillin in 
bacterial meningitis. Antimicrobial Agents and Chemotherapy S, 610 (1965) - 12. MCCRUMr, F. R., Hall, H. E., Imburg, J., Merideth, A., Helmbold, R.: Treatment of hemophilus influenzae meningitis with doloramphenicol and other antibiotics. J. A. M. A. 145, 469 (1951) 13. Mclinn, S. E., Nelson, J. D., Haltalin, K. C.: Antimicrobial susceptibility of Hemophilus influenzae. Pediatrics 45, 827 (1970) 14. Nelson, J. D.: Should Ampicillin Be Abandoned for Treatment of Hacmophilus influenzae Disease? J. A. M. A. 229, 322 (1974) - 15. Schiffer, M. S., Schneerson, R., MacLowry, J., Robbins, J. B., McReynolds, J. W., Thomas, W. J., Bailey, D. W., Clarke jr., E. J., Mueller, E. J. and Escamilia, J.: Clinical, Bacteriological and Immunological Characterisation of Ampicillin-Resistant Haemophilus Influenzac Type B. Lancet 3, 257 (1974) - 16. Schröter, W.: Hematologic side-effects of chloramphenicol. Neuropädiatrie 5, 117 (1974) - 17. SELl, S. H. W., Webb, W. W., Pate, J. E. and Doyne, E. O.: Psychological sequelae of bacterial meningitis: Controlled studies. Pediatrics 49, 212 (1972) -
18. Sмiтh, A.: Treatment of bacterial meningitis: Antimicrobial and general. Pediatrics 53, 597 (1974) - 19. Sproles, E. T., Azerrad, J., Willisamson, C. and Merril, R. E.: Meningitis due to hemophilus influenzae: Long-term sequelae. J. Pediat. 75, 782 (1969) - 20. Tноmas, W. J., McReynolds, J. W., Mock, C. R. and BAILeY, D. W.: Ampicillin-Resistant Haemophilus Influenzac Meningitis. Lancet 23, 313 (1974) - 21. Томeh, M. O., Stuart, E. S., McGowan, J. E., Terry, P. M. and Nahmias, A. J.: Ampicillin-Resistant Haemophilus influenzac Type B Infection. J. A. M. A. 229, 295 (1974) - 22. Thrupp, L. D., Leedom, J. M., Ivler, D., Wehrle, P. F., Portnoy, B. and Mathies, A. W.: Ampicillin levels in the cerebrospinal fluid during treatment of bacterial meningitis. Antimicrobial Agents and Chemotherapy S, 206 (1965) - 23. Turk, D. C.: Ampicillin-resistant Haemophilus influenzae meningitis. Lancet 1, 453 (1974) - 24. Young, L. M., Hassow, J. E. and Klein, J. O.: Relapse following ampicillin treatment of acute hemophilus influenzae meningitis. Pediatrics 41, 516 (1968). 